\title{
Physical Activity and Incidence of Atrial Fibrillation - Systematic Review and Meta- Analysis
}

\author{
Daniel Carlos Garlipp, ${ }^{\circledR}$ Raphael Boesche Guimaraes, ${ }^{\circledR}$ Simone Louise Savaris, ${ }^{\circledR}$ Clovis Froemming Junior, ${ }^{\circledR}$ \\ Oscar Dutra, ${ }^{\circledR}$ Tiago Luiz Luz Leiria ${ }^{\circledR}$ \\ Instituto de Cardiologia / Fundação Universitária de Cardiologia (IC/FUC), Rio Grande do Sul, RS - Brazil
}

\section{Abstract}

Background: The relationship between exercise and atrial fibrillation (AF) is controversial.

Objectives: To analyze the effects of physical activity on the incidence of atrial fibrillation using systematic review and meta-analysis.

Methods: Systematic review and meta-analysis of studies that relate physical exercise and atrial fibrillation. The following databases were searched: PubMed, BVS Saúde and Cochrane. The following descriptors were used: "atrial fibrillation", "exercise", "physical activity" and "exercise therapy". All prospective, retrospective, cross-sectional and cohort studies were investigated. All statistical analyzes were provided using Review Manager 5.3 to provide the mean difference (MD) and relative risk (RR) ratio with $95 \%$ confidence intervals $(95 \% \mathrm{CI})$. The statistical method of heterogeneity index was used to assess heterogeneity. Level of significance was $5 \%$.

Results: Combined analysis of 11 studies totaling 276,323 participants aged between 12 and 90 years did not suggest a significant increase in AF in individuals submitted to physical exercise $(\mathrm{RR}=0.914,95 \% \mathrm{CI}=0.833-1.003$, heterogeneity: $\mathrm{p}<0.001$ ).

Conclusions: Physical exercise, lato sensu, without stratification by intensity, sex or age does not seem to be associated with an increase of atrial fibrillation. (Int J Cardiovasc Sci. 2019;32(4):384-390)

Keywords: Exercise; Atrial Fibrillation; Asthma; Exercise Therapy; Cardiorespiratory Fitness; Review; MetaAnalysis as Topic.

\section{Introduction}

Atrial fibrillation $(\mathrm{AF})$ is the most frequent arrhythmia occurring in $0.1 \%-4.0 \%$ of the population and the prevalence increased to $7.2 \%$ in patients aged $\geq 65$, with an annual increase of $1.6 \%$ in patients aged $\geq 75$. Characterized by loss of atrial contraction capacity (loss of atrial systole), AF is responsible for almost onethird of hospitalizations for heart rhythm disturbances. It may present high morbidity and mortality due to hemodynamic involvement, cardiomyopathy due to tachycardia and thromboembolic phenomena.

Mailing Address: Tiago Luiz Luz Leiria

Av. Princesa Isabel, 395. Postal Code: 90620-000, Santana, Porto Alegre, RS - Brazil.

E-mail: pesquisa.leiria@gmail.com / drleiria@gmail.com
Risk factors for the development of AF include cardiac and non-cardiac factors such as age, structural heart disease, hypertension, diabetes mellitus and hyperthyroidism. ${ }^{1}$ The change in cardiac function is associated with increased mortality and risk of infarction, decreased quality of life, decreased exercise capacity and impaired left ventricular function. ${ }^{2}$

It is known that physical activity is an effective adjunct in the treatment of various types of cardiovascular diseases. However, patients with AF present decreased tolerance to exercise, dyspnea and palpitations. ${ }^{3}$ Some

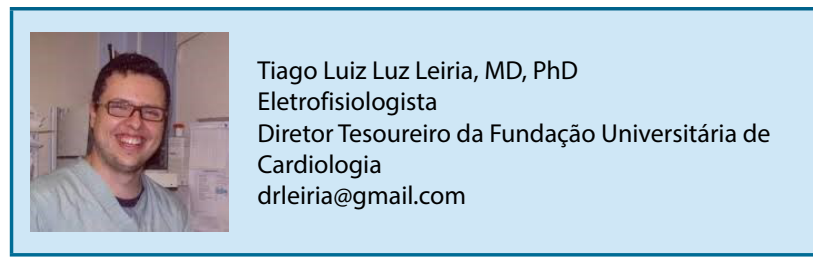


studies report a J or $\mathrm{U}$ curve between the correlation of intensity of physical activity and AF.4-10 On the other hand, some studies show a linear correlation between the amount of physical activity and the development of AF.11-14

Considering the regular practice of physical activity as a cardiovascular benefit and literature inconsistency about its potential arrhythmogenic effect, the objective of this study was to analyze the effects of physical activity on the incidence of AF.

\section{Methods}

\section{Data source and search}

In order to ensure a review of studies on the effects of physical exercise on the development of atrial fibrillation, we searched the following databases: PubMed, BVS Health and Cochrane. The following descriptors were used: "atrial fibrillation", "exercise", "physical activity" and "exercise therapy". The search was limited to articles published in English whose full texts were reviewed. We used prospective, retrospective, crosssectional and cohort studies. Data collection took place between September and October 2017 and data analysis was performed between October and December 2017. References in all articles included were examined for other relevant publications.

Participants were patients without AF who underwent physical exercise and were followed up. Figure 1 shows the flowchart of the meta-analysis selection process according to the Jadad quality scale.

\section{Criteria for data inclusion and extraction}

The inclusion criteria were as follows: (1) study design: all cohort studies, prospective, cross-sectional, observational and randomized clinical trials with patients who performed physical exercises and the development of AF. The studies were excluded from the analysis if: (1) they included patients with previous atrial fibrillation, (2) they included athletes and/or patients submitted to vigorous physical exercise (3) they could not extract concrete data from published results, such as comments, letters, cases, abstracts, reviews, experimental studies and animal studies, (4) the results were not clearly reported. Screening, selection, data extraction and risk of bias evaluation were performed independently and duplicated by two researchers and, ultimately, the potential of disagreement and disagreement was resolved by the corresponding author.

\section{Quality assessment}

The quality assessments were evaluated by the composite scale of Jadad, a numerical score of zero meaning the weakest to seven meaning the strongest. The scale contains the following points: (1) generation of random sequence (0-2), (2) concealment of allocation $(0-2)$, (3) blinding double (0-2), (4) description of withdrawals and drop-outs (0-1). The total score of 4-7 indicates high quality.

Methods of data synthesis and risk of bias in individual studies

All statistical analyses were provided using Review Manager 5.3 to provide the mean difference (MD) and the relative risk (RR) ratio with $95 \%$ confidence intervals $(95 \%$ CI). The statistical method of heterogeneity index was used to assess heterogeneity. The level of significance was 5\%.

\section{Results}

Search on the chosen databases resulted in 731 articles. After reviewing the titles, abstracts and articles repeated, a total of 11 studies were included in this systematic review.

\section{Study and characteristics of patients}

In the 11 studies included in the meta-analysis, there were 276,323 participants and, in the studies, the number of participants ranged from 2,014 to 81,317, with ages varying between 12 and 90 years. The characteristics of the studies and the patients are presented in Table 1.

Four studies were prospective (Bapat et al., ${ }^{6}$ Grundvold et al., ${ }^{7}$ Mokhayeri et al., ${ }^{8}$ Morseth et al., ${ }^{9}$ and Mozaffarian et al., ${ }^{10}$ ) with mean follow-up periods of $7.7,35,11,20$ and 12 years, respectively; a cohort study (Williams et al. ${ }^{14}$ ) with mean follow-up period of 6.2 years; a Post-Hoc analysis of a prospective study (Everett et al., ${ }^{13}$ ), a crosssectional study (Myrstad et al., ${ }^{11}$ ) and an observational study (Qureshi et al., ${ }^{12}$ ). In addition to these, one was a Post-Hoc analysis of a Randomized Clinical Trial (Aizer et al., ${ }^{4}$ ) with follow-up period of 12 years, and a prospective observational study (Azarbal et al., ${ }^{5}$ ) with follow-up period of 11.5 years. From the analyzed studies, no data were identified regarding patient hospitalization.

\section{Study of the effect of exercise on the population analyzed}

Figure 2 shows the results of the meta-analysis considering the selected studies. 


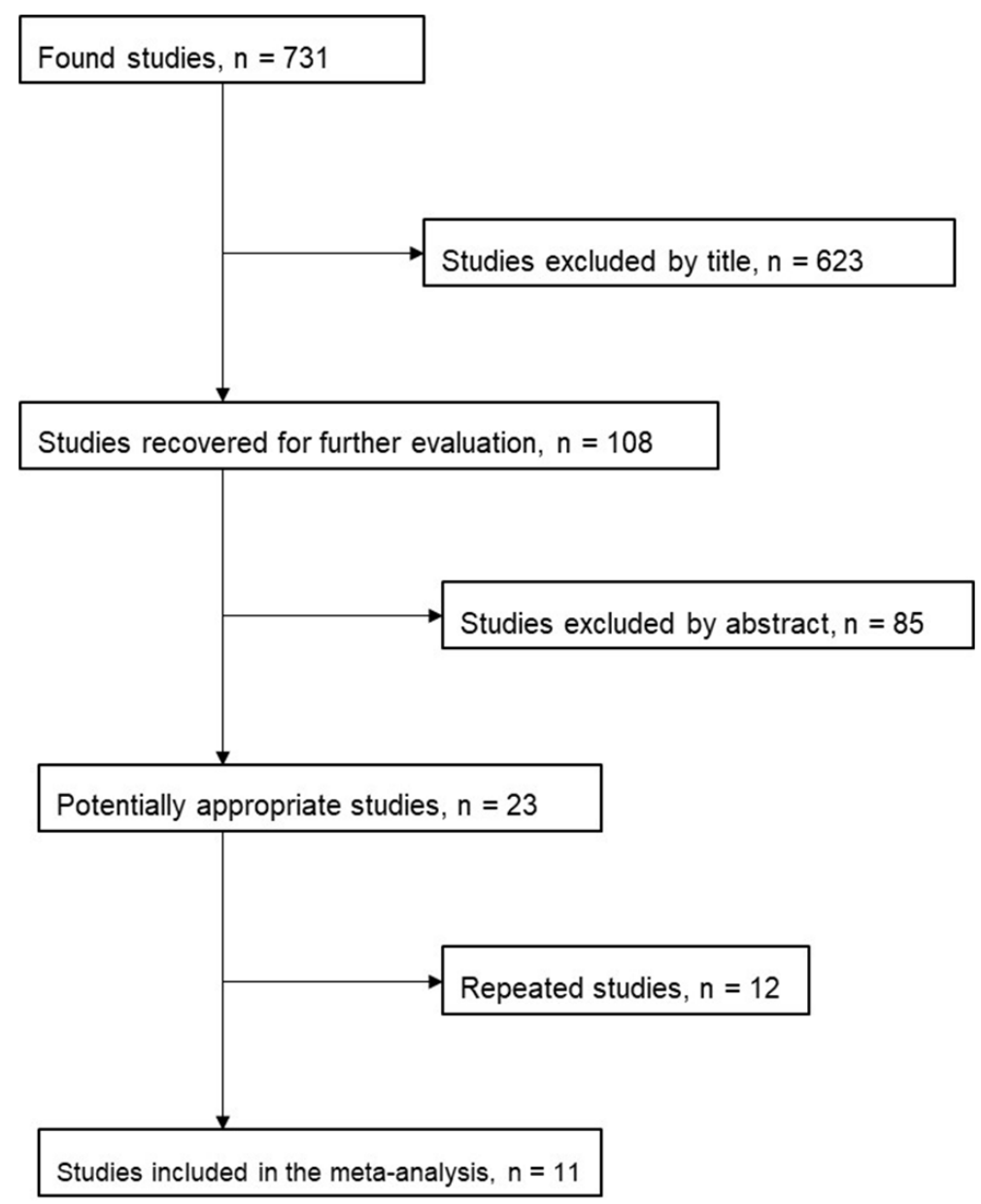

Figure 1 - Selection process of studies.

The combined analysis of the studies did not suggest a significant increase in AF in subjects submitted to exercise $(R R=0.914,95 \% C I=0.833-1.003$, heterogeneity: $p<0.001)$.

\section{Discussion}

Although the benefits of physical exercise on cardiovascular diseases are well described, the same does not occur in relation to AF. In this sense, the results of this meta-analysis, based on the studies analyzed, indicate that individuals who exercise are less likely to have AF.

Mozaffarian et al., ${ }^{10}$ suggest that mild and moderate activities, especially leisure activities such as walking, are associated with a significantly lower incidence of AF. On the other hand, Drca et al., ${ }^{15}$ observed an increased risk of the development of AF in men under 30 years of age submitted to high levels of exercise, and this does not occur at older ages. In this sense, Larsson et al., ${ }^{16}$ suggest that maintaining a body mass index (BMI) of less than 25 $\mathrm{kg} / \mathrm{m}^{2}$, doing more than 20 minutes of exercise daily, not consuming or consuming alcohol in a mild to moderate manner ( $\leq 2$ drinks / day for men and $\leq 1$ drink/day for women) and not smoking reduce the risk of developing AF by half.

Bapat et al., ${ }^{6}$ from the Multiethnic Atherosclerosis Study (MESA), associated physical activity and AF in a diverse population without clinically recognized cardiovascular disease. The results showed that neither vigorous physical activity nor total intentional exercise were independently related to $\mathrm{AF}$, when adjusted for some covariates. It has even been shown that the greater the relationship of the individual with vigorous activities, 
Table 1 - Characteristics of the studies included in the meta-analysis

\begin{tabular}{|c|c|c|c|c|c|c|}
\hline Study & Design & Date & $\begin{array}{l}\text { Sample } \\
\text { size }\end{array}$ & $\begin{array}{l}\text { Average } \\
\text { age }\end{array}$ & $\begin{array}{l}\mathrm{p} \text { value } \\
\text { adopted }\end{array}$ & Inclusion of participants \\
\hline Aizer et al. ${ }^{4}$ & $\begin{array}{c}\text { Post-Hoc } \\
\text { Analysis of a } \\
\text { Randomized } \\
\text { Clinical Trial }\end{array}$ & $\begin{array}{l}\text { Randomization in } 1982 \\
\text { with follow-up until } \\
2001\end{array}$ & 22.071 & $\begin{array}{l}40 \text { to } 84 \\
\text { years }\end{array}$ & 0.01 & $\begin{array}{c}\text { Participants from the } \\
\text { Physicians' Health Study } \\
\text { aged } 40-82 \text { years in } 1982 \text { and } \\
\text { randomized to aspirin and/ } \\
\text { or beta-carotene }\end{array}$ \\
\hline Azarbal et al..$^{5}$ & $\begin{array}{l}\text { Prospective } \\
\text { Observational }\end{array}$ & $\begin{array}{c}\text { Data from medical } \\
\text { centers collected } \\
\text { between } 1994 \text { and } 1998\end{array}$ & 81.317 & $\begin{array}{c}50 \text { to } 79 \\
\text { years }\end{array}$ & 0.01 & $\begin{array}{l}\text { Participants from the } \\
\text { Multi-Ethnic Study of } \\
\text { Atherosclerosis }\end{array}$ \\
\hline Bapat et al. $^{6}$ & $\begin{array}{l}\text { Prospective } \\
\text { Cohort }\end{array}$ & $\begin{array}{l}\text { The database is from } \\
2000 \text { to } 2002\end{array}$ & 5.793 & $\begin{array}{c}45 \text { to } 84 \\
\text { years }\end{array}$ & 0.05 & $\begin{array}{l}\text { Participants from the MESA } \\
\text { database }\end{array}$ \\
\hline Grundvold et al. ${ }^{7}$ & $\begin{array}{l}\text { Prospective } \\
\text { Cohort }\end{array}$ & $\begin{array}{l}\text { The database is from } \\
1972 \text { to } 1975\end{array}$ & 2.014 & $\begin{array}{c}40 \text { to } 59 \\
\text { years }\end{array}$ & 0.05 & $\begin{array}{l}\text { Five government institutions } \\
\text { in Oslo }\end{array}$ \\
\hline Mokhayeri et al. ${ }^{8}$ & $\begin{array}{l}\text { Prospective } \\
\text { Cohort }\end{array}$ & $\begin{array}{l}\text { Patients followed from } \\
\text { the years } 2000 \text { to } 2011\end{array}$ & 6.487 & $\begin{array}{c}45 \text { to } 84 \\
\text { years }\end{array}$ & 0.05 & $\begin{array}{l}\text { Participants from the } \\
\text { Multi-Ethnic Study of } \\
\text { Atherosclerosis }\end{array}$ \\
\hline Morseth et al..$^{9}$ & $\begin{array}{l}\text { Prospective } \\
\text { Cohort }\end{array}$ & $\begin{array}{c}\text { The database is from } \\
1986 / 7\end{array}$ & 4.791 & $\begin{array}{c}12 \text { to } 67 \\
\text { years }\end{array}$ & 0.05 & Tromsø Study participants \\
\hline Mozaffarian et al. ${ }^{10}$ & $\begin{array}{l}\text { Prospective } \\
\text { Cohort }\end{array}$ & $\begin{array}{l}\text { The database is from } \\
1999 \text { to } 2001\end{array}$ & 5.446 & $\geq 65$ years & 0,05 & $\begin{array}{l}\text { Participants from the } \\
\text { Cardiovascular Health Study }\end{array}$ \\
\hline Myrstad et al. ${ }^{11}$ & Transversal & The database is for 2009 & 2.277 & $\begin{array}{c}65 \text { to } 90 \\
\text { years }\end{array}$ & 0.001 & $\begin{array}{l}\text { Elderly men undergoing } \\
\text { long-term sports }\end{array}$ \\
\hline Qureshi et al. ${ }^{12}$ & Observational & $\begin{array}{l}\text { The database is from } \\
1991 \text { to } 2009\end{array}$ & 64.561 & $\begin{array}{c}\text { Extracts } \\
\text { of ages } \\
(<40,40- \\
49,50-59 \\
\geq 60)\end{array}$ & 0.05 & $\begin{array}{c}\text { Participants from the Henry } \\
\text { Ford Exercise Testing (FIT) } \\
\text { Project }\end{array}$ \\
\hline Everett et al. ${ }^{13}$ & $\begin{array}{c}\text { Post-Hoc analysis } \\
\text { of a prospective } \\
\text { study }\end{array}$ & $\begin{array}{l}\text { Beginning in } 1993 \text { and } \\
\text { randomization in } 2004\end{array}$ & 34.759 & $\geq 45$ years & 0.05 & $\begin{array}{l}\text { Women participating in the } \\
\text { Women's Health Study }\end{array}$ \\
\hline Williams et al. ${ }^{14}$ & Cohort & $\begin{array}{l}\text { Partial reevaluation } \\
\text { of } 2006 \text { from the } \\
\text { National Health Study } \\
\text { of Corridors II and } \\
\text { the National Walkers' } \\
\text { Health Study }\end{array}$ & 46.807 & $\begin{array}{c}33 \text { to } 72 \\
\text { years }\end{array}$ & 0.05 & $\begin{array}{l}\text { Participants from the national } \\
\text { study of runners and walkers } \\
\text { for health }\end{array}$ \\
\hline
\end{tabular}

the lower the risk of AF. Also, Ofman et al., ${ }^{17}$ after metaanalysis involving 95,526 individuals, did not identify a statistically significant association between regular physical activity and increased incidence of AF. In this sense, the guidelines recommend performing at least 150 minutes of moderate physical activity or 75 minutes of intense physical activity per week. ${ }^{18}$
Patients with AF report symptoms such as decreased exercise tolerance, dyspnea, palpitations and fatigue, which directly affect the quality of life. However, physical exercise and training decrease these symptoms, and may have antiarrhythmic effects in individuals with paroxysmal AF, as well as protect against the development of AF. ${ }^{19}$ In this sense, in order to verify 
Studies

Aizer A 2009

Azarbal F 2014

Bapat A 2015

Grundvold I 2013

Mokhayeri Y 2017

Morseth B 2016

Mozaffarian D 2008

Myrstad M 2014

Qureshi WT 2015

Everett 2011

williams 2013

Overall $\left(\left.\right|^{\wedge} 2=8317 \%, P<0.001\right)$
Estinate (958 C.I.)

$1.200(1.021,1.410)$

$0.900(0.844,0.960)$

$0.974(0.719,1.320)$

$1.600(1.133,2.260)$

$0.947(0.583,1.537)$

$0.909(0.768,1.076)$

$0.638(0.514,0.791)$

$1.816(1.042,3.164)$

$0.930(0.920,0.940)$

$0.793(0.682,0.921)$

$0.711(0.627,0.806)$

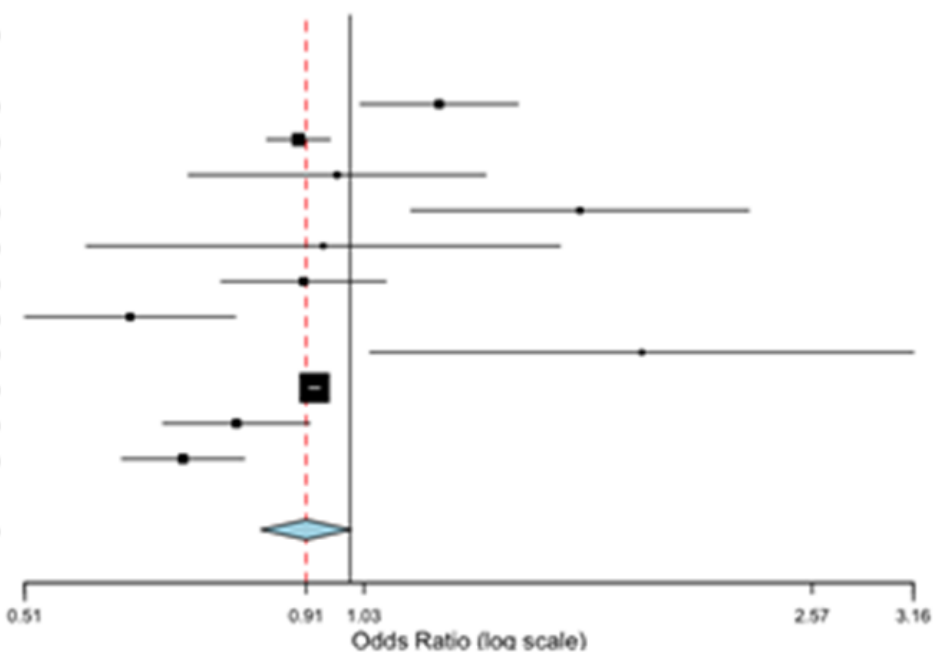

Figure 2 - Risk of incidence of atrial fibrillation in individuals submitted to physical exercises.

the effects of training on the functional capacity of individuals with AF, Luo et al., ${ }^{20}$ submitted patients with $\mathrm{AF}$ and patients after myocardial infarction with reduced ejection fraction to supervised training with aerobic exercises, three times a week for 36 sessions, then moving on to a home program for another two years. The training was efficient, resulting in increased cardiorespiratory capacity and peak $\mathrm{VO}_{2}$ in both groups, but no significant differences were identified between the groups.

The international guidelines recommend the practice of physical activity in patients with $\mathrm{AF}$ in order to reduce their comorbidities. ${ }^{21}$ When Malmo et al., ${ }^{22}$ submitted 26 AF patients to interval aerobic training, demonstrated that 12 weeks were enough to decrease arrhythmic load, besides causing a decrease in the symptoms related to AF. In addition, improvement in maximum work capacity, atrial and left ventricular function, lipid levels and quality of life were identified. For Osbak et al., ${ }^{3}$ patients with heart disease lose muscle mass and strength due to inactivity and local hemodynamic changes. This way, developing strategies that allow the increase of muscle strength in these patients becomes important in order to increase mobility, posture and balance.

In an observational study of 20,000 adults, Proietti et al. ${ }^{23}$ observed lower all-cause mortality in AF patients who reported being involved with regular physical activity. Still, Hegbom et al., ${ }^{24}$ and Plisiene et al., ${ }^{25}$ demonstrated improvements promoted by physical exercise in quality of life, in addition to the reduction of symptoms in patients with AF.

According to Anderson and Taylor, ${ }^{26}$ physical capacity is the main clinical outcome of cardiac rehabilitation, regardless of diagnosis. For each increase of 1 Metabolic Equivalent (MET) in physical capacity, mortality rate decreases by $17 \%$ in men and $14 \%$ in women. Thus, physical exercise seems safe for patients with AF besides triggering several benefits. ${ }^{27}$

Another important factor is the strong relationship between obesity and AF. According to Pathak et al., ${ }^{28}$ electrical factors and structural remodeling caused by obesity lead to the genesis and perpetuation of AF. In this sense, physical exercise, in addition to assisting in weight loss and consequent reduction in AF recurrence, ${ }^{5,29}$ may protect against AF even in the presence of obesity. ${ }^{30}$

The study by Pathack et al., ${ }^{31}$ showed that an increase in cardiorespiratory fitness around 2 METs was associated with reduced density of AF. According to Abed et al., ${ }^{32}$ decrease in AF density due to exercise can be explained by increased cardiorespiratory capacity and weight loss. Increase in each metabolic equivalent (MET) results in a $20 \%$ decrease in the risk of recurrence of $\mathrm{AF}^{32}$ Skielboe et al. ${ }^{33}$ in order to verify if high-intensity exercises were more effective in decreasing AF density than low-intensity exercises, did not identify differences. However, it has 
been shown that high-intensity exercises do not increase risk and that patients tolerate exercises of this type.

Regular practice of physical activity has been reported to increase vagal tonus due to physiological adaptations resulting from increased cardiac work, ${ }^{34}$ inducing electrical stability of the heart and maintenance of homeostasis. In this sense, low resting HR tends to represent a good health picture..$^{35}$ Thus, well-trained or physically conditioned individuals have lower resting HR, which suggests greater parasympathetic activity ${ }^{36}$ or less sympathetic activity. ${ }^{37}$ Still, Uusitalo et al., ${ }^{38}$ and Bonaduce et al., ${ }^{39}$ doing studies with longitudinal characteristics, observed a reduction in resting HR, although significant abnormalities in the autonomic indicators were not identified. Thus, Catai et al., ${ }^{40}$ suggest that exercise-induced bradycardia may result from intrinsic sinus node adaptations.

Like any systematic review, this study also presents limitations, since the results demonstrated here are limited by the quality of the studies available. This way, trying to make a complete literature review, all studies available, on the proposed theme, were included, and were evaluated, however, with a robust quality metaanalysis technique. In addition, the data analyzed were not stratified by type of exertion, gender or age.

\section{Conclusion}

It is concluded, therefore, that physical exercise, lato sensu, without stratification by intensity, sex or age, does not seem to be associated with an increase in the occurrence of atrial fibrillation.

\section{Acknowledge}

The postgraduate team of the Institute of Cardiology of Porto Alegre.

\section{References}

1. Benjamin EJ, Wolf PA, D'Agostino RB, Silbershatz H, Kannel WB, Levy D. Impact of atrial fibrillation on the risk of death: the Framingham Heart Study. Circulation. 1998; 98(10):946-52.

2. Wattigney WA, Mensah GA, Croft JB. Increasing trends in hospitalization for atrial fibrillation in the United States, 1985 through 1999: implications for primary prevention. Circulation. 2003;108(6):711-6.

3. Osbak PS, Mourier M, Henriksen JH, Kofoed KF, Jensen GB. Effect os physical exercise training on muscle strength and body composition, and their association with functional capacity and quality os life in patients with atrial fibrillation: a randomized controlled trial. J Rehabil Med 2012;44(11):975-9.

\section{Author contributions}

Conception and design of the research: Garlipp DC, Leiria TLL. Acquisition of data: Garlipp DC, Guimarães RB, Savaris SL, Froemming Junior C, Dutra O. Analysis and interpretation of the data: Garlipp DC, Guimarães RB, Savaris SL, Froemming Junior C, Dutra O, Leiria TLL. Statistical analysis: Froemming Junior C, Leiria TLL. Writing of the manuscript: Garlipp DC, Guimarães RB, Savaris SL, Froemming Junior C, Dutra O, Leiria TLL. Critical revision of the manuscript for intellectual content: Leiria TLL.

\section{Potential Conflict of Interest}

No potential conflict of interest relevant to this article was reported.

\section{Sources of Funding}

There were no external funding sources for this study.

\section{Study Association}

This article is part of the thesis of postgraduate submitted by Daniel Carlos Garlipp, from Instituto de Cardiologia / Fundação Universitária de Cardiologia do Rio Grande do Sul.

\section{Ethics approval and consent to participate}

This study was approved by the Ethics Committee of the IC/FUC under the protocol number 1797.204. All the procedures in this study were in accordance with the 1975 Helsinki Declaration, updated in 2013. Informed consent was obtained from all participants included in the study.

4. Aizer A, Gaziano JM, Cook NR, Manson JE, Buring JE, Albert CM. Relation of vigorous exercise to risk of atrial fibrillation. Am J Cardiol. 2009;103(11):1572-7.

5. Azarbal F, Stefanick ML, Salmoirago-Blotcher E, Manson JE, Albert CM, LaMonte MJ, et al. Obesity, physical activity, and their interaction in incident atrial fibrillation in postmenopausal women. J Am Heart Assoc. 2014;3(4):pii.e001127

6. Bapat A, Zhang Y, Post WS, Guallar E, Soliman EZ, Heckbert SR, et al. Relation of physical activity and incident atrial fibrillation (from the Multi-Ethnic Study of Atherosclerosis). Am J Cardiol. 2015;116(6):883-8. 
7. Grundvold I, Skretteberg PT, Liestøl K, Erikssen G, Engeseth K, Gjesdal $\mathrm{K}$, et al. Low heart rates predict incident atrial fibrillation in healthy middle-aged men. Circ Arrhythm Electrophysiol. 2013;6(4):726-31.

8. Mokhayeri Y, Hashemi-NazariSS, Mansournia MA, Soori H, Khodakarim $\mathrm{S}$. The association between physical activity and atrial fibrillation applying the Heaviside function in survival analysis: The Multi-Ethnic Study of Atherosclerosis. Epidemiol Health. 2017;39:e2017024.

9. Morseth B, Graff-Iversen S, Jacobsen BK, Jørgensen L, Nyrnes A, Thelle DS, et al. Physical activity, resting heart rate, and atrial fibrillation: the Tromsø Study. Eur Heart J. 2016;37(29):2307-13.

10. Mozaffarian D, Furberg CD, Psaty BM, Siscovick D. Physical Activity and Incidence of Atrial Fibrillation in Older Adults: The Cardiovascular Health Study: Mozaffarian-Physical activity and atrial fibrillation. Circulation. 2008;118(8):800-7.

11. Myrstad M, Løchen M-L, Graff-Iversen S, Gulsvik AK, Thelle DS, Stigum $\mathrm{H}$, et al. Increased risk of atrial fibrillation among elderly Norwegian men with a history of long-term endurance sport practice. Scand J Med Sci Sports. 2014;24(4):e238-e244.

12. Qureshi WT, Alirhayim Z, Blaha MJ, Juraschek SP, Keteyian SJ, Brawner CA, et al. Cardiorespiratory Fitness and Risk of Incident Atrial Fibrillation. Results from the Henry Ford Exercise Testing (FIT) Project. Circulation. 2015;131(21):1827-34.

13. Everett BM, Conen D, Buring JE, Moorthy MV, Lee IM, Albert CM. Physical Activity and the Risk of Incident Atrial Fibrillation in Women. Circ Cardiovasc Qual Outcomes. 2011;4(3):321-7.

14. Williams PT, Franklin BA. Reduced Incidence of Cardiac Arrhythmias in Walkers and Runners. Plos One. 2013;8(6):e65302.

15. Drca N, Wolk A, Jensen-Urstad M, Larsson SC. Atrial fibrillation is associated with different levels of physical activity levels at different ages in men. Heart. 2014;100(13):1037-42.

16. Larsson SC, Drca N, Jensen-Urstad M, Wolk A. Combined impact of healthy lifestyle factors on risk of atrial fibrillation: Prospective study in men and women. Int J Cardiol. 2016 jan 15;203,46-9.

17. Ofman $\mathrm{P}, \mathrm{Khawaja} \mathrm{O}$, Rahilly-Tierney CR, Peralta A, Hoffmeister P, Reynolds MR, et al. Regular physical activity and risk of atrial fibrillation. A systematic review and meta-analysis. Circ Arrhythm Electrophysiol. 2013;6(2):252-6

18. Physical Activity Guidelines Advisory Committee Report, 2008. To the secretary of health and human services. Part a: executive summary. Nutr Rev. 2009; 67(2):114-20.

19. Kapa S, Asirvatham SJ. A MET a day keeps arrhythmia at bay: the association between exercise or cardiorespiratory fitness and atria fibrillation. Mayo Clin Proc. 2016;91(5):545-50.

20. Luo N, Merrill P, Parikh KS, Whellan DJ, Piña IL, Fiuzat M, et al. Exercise training in patients with chronic heart failure and atrial fibrillation. J Am Coll Cardiol. 2017;69(13):1683-91.

21. Eckel RH, Jakicic JM, Ard JD, de Jesus JM, Houston Miller N, Hubbard VS, et al. 2013 AHA/ACC guideline on lifestyle management to reduce cardiovascular risk: a report of the American College of Cardiology/ American Heart Association Task Force on Practice Guidelines. Circulation. 2014;129(Suppl 2):S76-99.

22. Malmo V, Nes BM, Amundsen BH, Tjonna AE, Stoylen A, Rossvoll O, et al. Aerobic interval training reduces the burden of atrial fibrillation in the short term: a randomized trial. Circulation. 2016;133(5):466-73.

23. Proietti M, Boriani G, Laroche C, Diemberger I, Popescu MI, Rasmussen $\mathrm{LH}$, et al. Self-reported physical activity and major adverse events in patients with atrial fibrillation: a report from the EURObservational Research Programmed Pilot Survey on Atrial Fibrillation (EORP-AF) General Registry. Europace. 2017;19(4):535-43.
24. Hegbom F, Stavem K, Sire S, Heldal M, Orning OM, Gjesdal K. Effects of short-term exercise training on symptoms and quality of life in patients with chronic atrial fibrillation. Int J Cardiol. 2007;116(1):86-92.

25. Plisiene J, Blumberg A, Haager G, Knackstedt C, Latsch J, Norra C, et al. Moderate physical exercise: a simplified approach for ventricular rate control in older patients with atrial fibrillation. Clin Res Cardiol. 2008;97(11):820-6.

26. Anderson L, Taylor R. Cardiac rehabilitation for people with heart disease: An overview of Cochrane systematic reviews. Int J Cardiol. 2014;177(2):348-61.

27. Giacomantonio NB, Bredin SS, Foulds HJ, Warburton DE. A systematic review of the health benefits of exercise rehabilitation in persons living with atrial fibrillation. Can J Cardiol. 2013;29(4)483-91.

28. Pathak RK, Mahajan R, Lau DH, Sanders P. The implications of obesity for cardiac arrhythmia mechanisms and management. Can J Cardiol. 2015;31(2):203-10.

29. Huxley RR, Misialek JR, Agarwal SK, Loehr LR, Soliman EZ, Chen LY, et al. Physical activity, obesity, weight change, and risk of atrial fibrillation: the Atherosclerosis Risk in Communities study. Circ Arrhythm Electrophysiol. 2014;7(4):620-5.

30. Pathak RK, Middeldorp ME, Meredith M, Mehta AB, Mahajan R, Wong CX, et al. Long-Term Effect of Goal-Directed Weight Management in an Atrial Fibrillation Cohort: A Long-Term Follow-Up Study (LEGACY). J Am Coll Cardiol. 2015;65(20):2159-69.

31. Pathak RK, Middeldorp ME, Lau DH, Mehta AB, Mahajan R, Twomey $D$, et al. Aggressive risk factor reduction study for atrial fibrillation and implications for the outcome of ablation: the ARREST-AF cohort study. J Am Coll Cardiol. 2014;64(21):2222-31.

32. Abed HS, Wittert GA, Leong DP, Shirazi MG, Bahrami B, Middeldorp $\mathrm{ME}$, et al. Effect of weight reduction and cardiometabolic risk factor management on symptom burden and severity in patients with atrial fibrillation: a randomized clinical trial. JAMA 2013;310(19):2050-60.

33. Skielboe AK, Bandholm TQ, Hakmann S, Mourier M, Kallemose T, Dixen U. Cardiovascular exercise and burden of arrhythmia in patients with atrial fibrillation - A randomized controlled trial. Plos One. 2017;12(2):e0170060.

34. Vanderlei LCM, Pastre CM, Hoshi RA, Carvalho TD, Godoy MF. Noções básicas de variabilidade da frequência cardíaca e sua aplicabilidade clínica. Rev Bras Cir Cardiovasc. 2009;24(2):205-17.

35. Greenland P, Daviglus ML, Dyer AR, Liu K, Huang CF, Goldberger $\mathrm{JJ}$, et al. Resting heart rate is a risk factor for cardiovascular and noncardiovascular mortality: the Chicago Heart Association Detection Project in Industry. Am J Epidemiol. 1999;149(9):853-62.

36. Aubert AE, Beckers F, Ramaekers D. Short-term heart rate variability in Young athletes. J Cardiol. 2001;37(Suppl 1):S85-8.

37. Chacon-Mikahil MPT, Forti VAM, Catai AM, Szrajer JS, Golfeti R, Martins LEB, et al. Cardiorespiratory adaptations induced by aerobic training in middle-age men: the importance of a decrease in sympathetic stimulation for the contribution of dynamic exercise tachycardia. Braz J Med Biol Res. 1998;31(5):705-12.

38. Uusitalo ALT, Uusitalo AJ, Ruscko HK. Exhaustive endurance training for 6-9 weeks did not change in intrinsic heart rate and cardiac autonomic modulation in female athletes. Int J Sports Med. 1998;19(8):532-40.

39. Bonaduce D, Petretta M, Cavallaro V, Apicella C, Ianniciello A, Romano $\mathrm{M}$, et al. Intensive training and cardiac autonomic control in high level athletes. Med Sci Sports Exerc. 1998;30(5):691-6.

40. Catai AM, Chacon-Mikahil MP, Martinelli FS, Forti VAM, Silva E, Golfetti $\mathrm{R}$, et al. Effects of aerobic exercise training on heart rate variability during wakefulness and sllep and cardiorespiratory responses of Young and middle-age healthy men. Braz J Med Biol Res. 2002;35(6):741-52. 